\title{
Optimization of the Production Process, Characterization and Efficiency of a Linear Detonation Shaped Charge with a Small Linear Mass of the Explosive Core
}

\author{
Dušan Vračarić ${ }^{1)}$ \\ Slavica Terzić ${ }^{1)}$
}

\begin{abstract}
This paper presents an optimization of the production process of the Linear Detonation Shaped Charge (LDSC) of a small linear mass of the explosive charge by rolling technology. Quality requirements and basic features of the produced LDSCs are given, as well as the test results of the reliability of their initiation and detonation run through the entire LDSC length. The results of the LDSC cutting efficiency on two kinds of materials of various thickness are presented and analyzed. The cutting tests are performed on the canopy of the LASTA training aircraft by the system for cutting, in static conditions. The obtained results are analyzed and presented in photographs
\end{abstract}

Key words: aircraft, cockpit, acrylate glass, detonation cutting, graphitized RDX, technological process, rolling, cumulative effect, test results.

\section{Used symbols}

LDSC - Linear Detonation Shaped Charge

Al $\quad-$ Aluminum

LASTA - Swallow, training aircraft

\section{Introduction}

$\mathrm{T}$ HE LDSC is a dihedral explosive charge of a length over $5 \mathrm{~m}$. It consists of a linear explosive charge and is used for cutting different profiles and sizes of various materials. Cutting process is realized with the cumulative effect, which is achieved with a specific form and characteristics of the explosive charges and metal confinement. LDSC demands homogeneity of the explosive charge and the cross-section symmetry. Various metal alloys and high explosives (such as penthrite (PETN), hexanitrostilbene (HNS), hexogen (RDX) and octogen (HMX) and their compositions) are commonly used for its production $[1,2]$.

The subject of this paper is a LDSC with a small linear mass of the explosive charge, less than $0,6 \mathrm{~g} / \mathrm{m}$ (so-called "small-mass" LDSC) and large length (over $5 \mathrm{~m}$ ). The Military Technical Institute (VTI) produces LDSC and it is used as the component of the cutting system for the LASTA canopy ("Canopy cutting system"). It can also be used for other purposes.

During the creation and production of LDSC, two relatively contrary requirements should be complied:

- LDSC should accept the initiation and cut effectively the $4 \mathrm{~mm}$ - thickness acrylic glass (requires a high enough linear mass of the explosive).

- LDSC should not endanger the pilot's life despite the fact of their vicinity to the cutting system (which requires decreasing the mass of the explosive as much as possible).
The solution lies in finding the "right measure", i.e. the minimum amount of explosives that can be homogeneously distributed per meter of LDSC, while having 100\% certainty for accepting the initiation to effectively cut the desired thickness of acrylate glass.

\section{Quality requirements and components of LDSC}

For the purpose of safe, reliable and efficient materials cutting, LDSC should have the following characteristics:

- Reliable initiation by the detonation cap DK8, or initial cap E-67 P1;

- Uninterrupted detonation along the entire length of LDSC;

- Precise and complete cutting of material;

- Minimum detonation velocity of $6000 \mathrm{~m} / \mathrm{s}$;

- Specific geometry and dimensions of the cross-section $\left(1,19 \mathrm{~mm}^{2}\right)$, as shown in Fig. 1 .

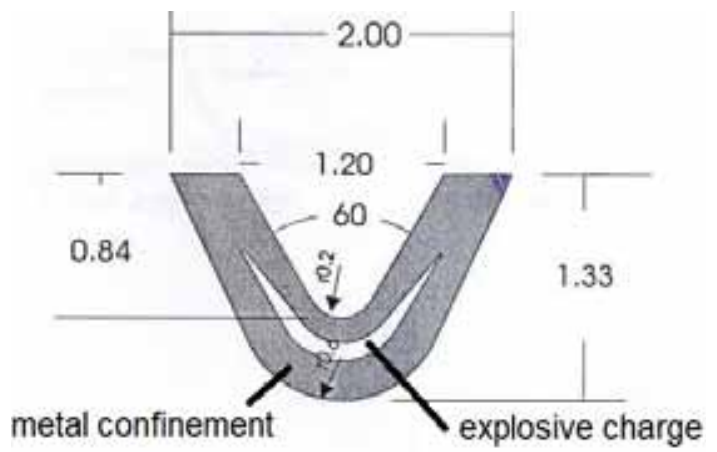

Figure 1. Cross-section of LDSC (mm)

The samples of LDSC were made by the rolling technology. The tubes of lead alloys $(\varnothing 8 / 5 \mathrm{~mm}$ outer/inner

\footnotetext{
1) Military Technical Institute (VTI), Ratka Resanovića 1, 11132 Belgrade, SERBIA

Correspondence to: Slavica Terzić; e-mail: slavica@algodesk.com
} 
diameter) were used as a confinement, and a graphitized RDX was used as the explosive charge [3]. The RDX is a high crystalline explosive which has been successfully used for a long time for various military purposes due to its good chemical and thermal stability and excellent compatibility with metal materials.

Characteristics of RDX are given in Table 1.

Table 1. Characteristics of RDX

\begin{tabular}{||c|c|}
\hline Characteristic & Value \\
\hline \hline Oxygene balance, $\%$ & $-21,6$ \\
\hline Volume of detonation gases, $1 / \mathrm{kg}$ & 900 \\
\hline Density, $\mathrm{g} / \mathrm{cm}^{3}$ & $1,81-1,82$ \\
\hline Melting temperature, ${ }^{\circ} \mathrm{C}$ & 204 \\
\hline Flash point, ${ }^{\circ} \mathrm{C}$ & 229 \\
\hline Explosion temperature, ${ }^{\circ} \mathrm{C}$ & 3380 \\
\hline Detonation velocity, $\mathrm{m} / \mathrm{s}$ & 8750 \\
${\text { (confined, density } \mathrm{g} / \mathrm{cm}^{3} \text { ) }}^{3}$ & 1,76 \\
\hline Trauzl test, $\mathrm{cm}^{3} / 10 \mathrm{~g}$ & 480 \\
\hline Friction sensitivity, J & 7,5 \\
\hline Impact sensitivity, $\mathrm{N}$ & 120 \\
\hline
\end{tabular}

Reducing the static electricity and desensitization of RDX crystals is done by their sieving and graphitizing. A small amount of the graphite powder positively affects the flow characteristics, "packaging" and compacting of RDX crystals inside the lead tube during the LDSC production.

Some of the metallurgical characteristics of the lead and its alloys include the ability to shape during plastic deformation and, on the other hand, there is a recrystallization of lead which takes place at room temperature in an early stage of the deformation. Because of that, these materials are an excellent choice for the production of LDSC with small cross-sectional dimensions.

Mechanical characteristics of pure lead were improved by adding antimony. This facilitated the production in the final stages. Larger tubes (outer/inner diameter $=9 / 6$ or $8 / 5$ $\mathrm{mm}$ ) were filled by the graphitized RDX, which simplified the production of LDSC.

\section{Metallurgical aspects of the LDSC production}

The shaping process of lead filled by the graphitized RDX (filled lead tubes) was carried out on the calibrated rollers, circle to circle system, that brings the outer diameter of the LDSC semi-product up to $Ø 1,5 \mathrm{~mm}$ [4].

The calibrated rollers system provides deformation of the filled lead tube (Fig.2) so that the changes of shape and wall thickness of lead tubes come simultaneously with the increase in density of the explosive charge. The bulk density of explosive (Fig.2), before starting the rolling process of the filled lead tubes, was between 1,1 and $1,2 \mathrm{~g} / \mathrm{cm}^{3}$.

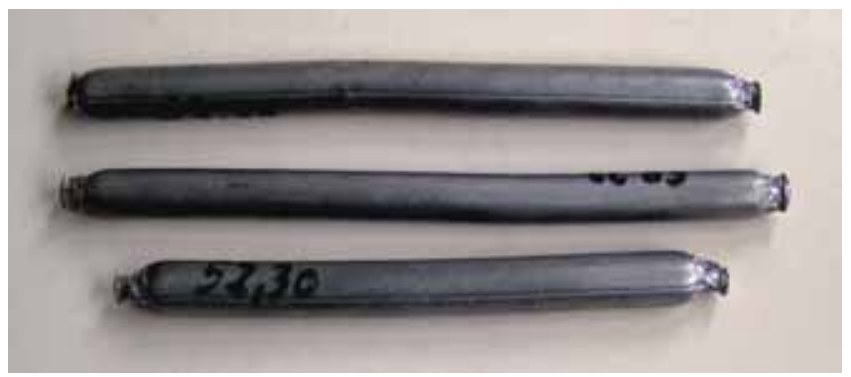

Figure 2. The lead tubes filled with graphitized RDX - blanks

The basic principle for designing the roll-pass design through calibration system, during the rolling process of metal materials, was the law of volume constancy. Partial and total degrees of deformation and elongation ratios were determined by applying this law.

The necessary calculation (prediction) of diameter, wall thickness and the initial length of lead tubes are complicated by the change of explosive's density (from $1,1 \mathrm{~g} / \mathrm{cm}^{3}$ to $1,75 \mathrm{~g} / \mathrm{cm}^{3}$ ) in different phases of LDSC manufacturing.

Reduction of the LDSC semi product diameter was done with the calibration rollers during the rolling process, Fig.3-5.

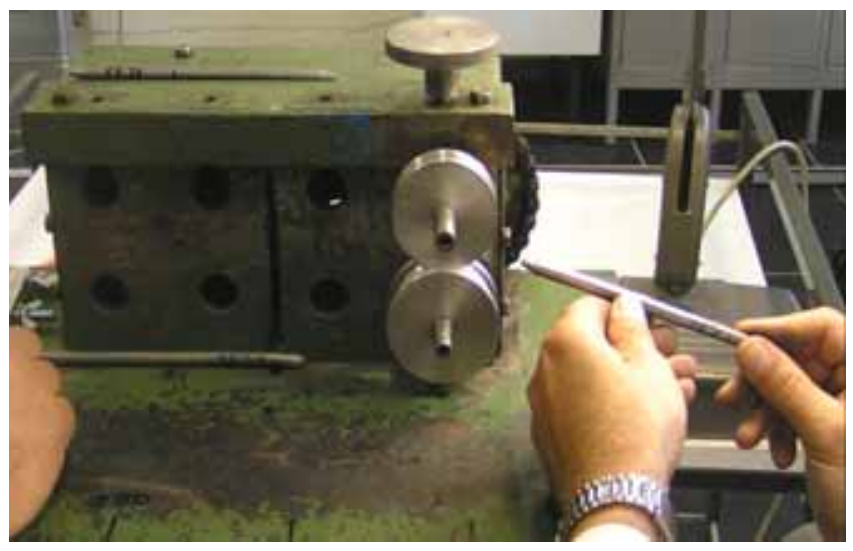

Figure 3. Starting phase of the manufacturing process of LDSC

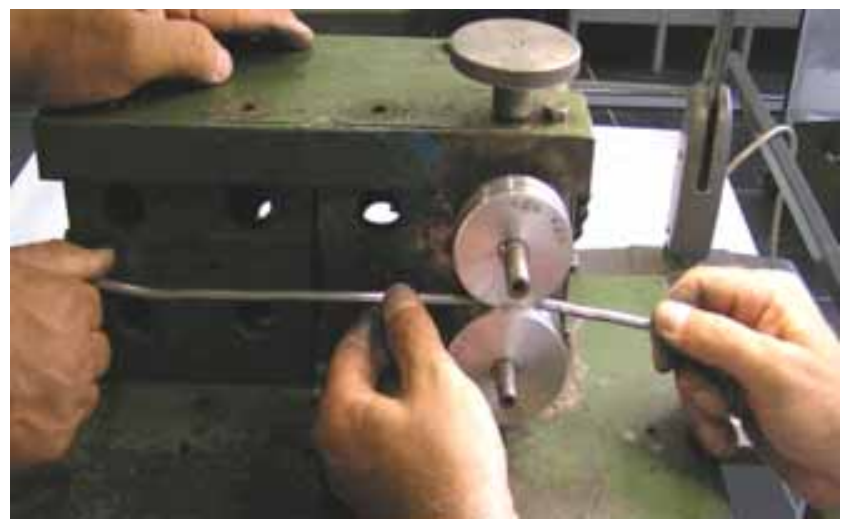

Figure 4. Manufacture of the LDSC's semi-product on the calibrated rollers

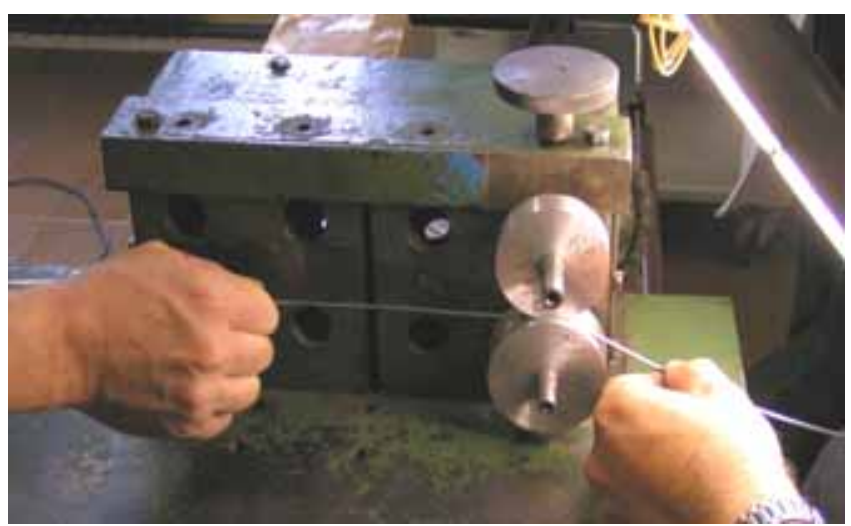

Figure 5. Shaping of the final LDSC's form on the calibrated rollers

After the rolling process on the profiled rollers ended, the required shape and dimensions of the LDSC's crosssection are ensured.

The thickness of the LDSC wall and distribution of explosives fill inside the LDSC semi-product (at different stages of the LDSC manufacturing), were controlled with metallographic methods at a cross section of the LDSC sample.

The cross-section of the two semi-LDSC samples at different stages of the production is shown in Fig.6. 


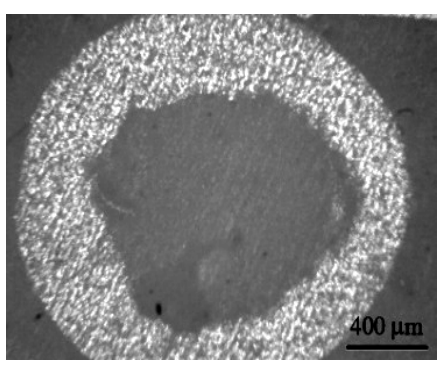

a) $\varnothing 2 \mathrm{~mm}$

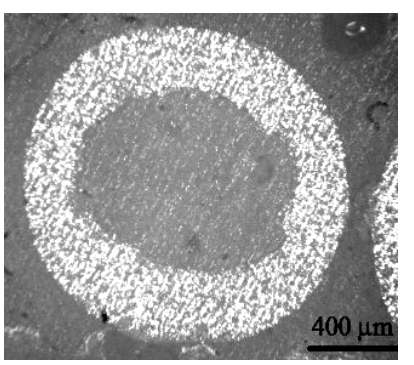

b) $\varnothing 1,4 \mathrm{~mm}$
Figure 6. Cross-section of two samples of the LDSC's semi-product

The external contours of the LDSC's semi-products (Fig.6) were approximately circular which fully satisfied the requirements of the LDSC development and production at this stage. The inner surface of the LDSC semi-products were not completely round because the density of explosive fill did not reach high enough value to provide sufficient support (or resistance) for the proper distribution of mechanical stress during the rolling process.

The above is confirmed by a little irregular shape of the Ø2,0 mm LDSC's semi-product (Fig.6-a), opposite to the diameter of 1,4 mm LDSC's cross-section (Fig.6-b).

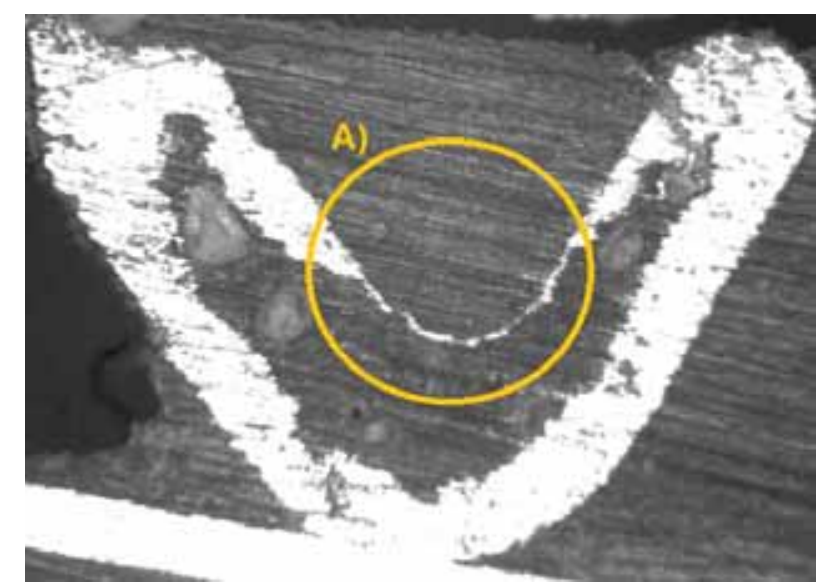

Figure 7. The cross-section of LDSC: direct transition from a round shape to the "V" form

The "round - round" application system was limited to the production stage of the $\varnothing 1,4 \mathrm{~mm}$ LDSC's semi-product. After the analysis of the LDSC cross sections, the process of direction transition from a round shape to the "V" form of LDSC is abandoned. The cross-section of LDSC was produced by a direct transition from a round shape to the "V" form (Fig.7).

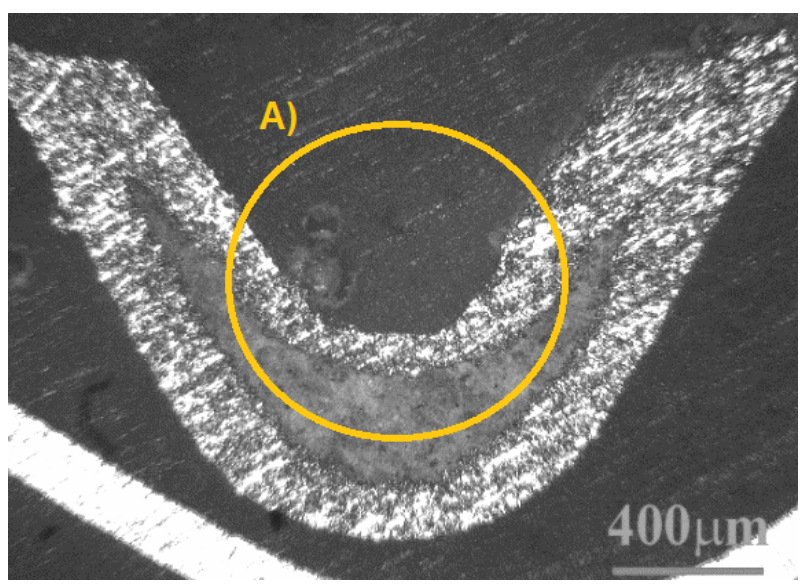

Figure 8. The cross-section of LDSC: new-designed calibre system
The inside walls of LDSC were very inhomogeneous and thin (Fig.7, detail A) which could easily lead to cracking of LDSC during production and manipulation.

In obtaining the final form of the LDSC (Fig.1) a different calibre system was designed to ensure the required shape, dimensions and projected wall thickness of lead coat and explosive fill $[5,6]$.

The new-designed calibre system used (defined geometry and the order of passing through the calibrated rollers) allows better distribution of deformation which gives homogeneous lead coat and improved high quality of LDSC (Fig.8, detail A).

It is possible to produce LDSC with a wide range of linear mass of the explosive core, various dimensions of cross-section and great length by changing the parameters of the LDSC's process technology.

\section{Determination of the LDSC quality}

\section{Detonation velocity of LDSC}

Detonation velocity was determined by the electronic counter. Experimentally obtained detonation velocities of LDSC are shown in Table 2.

Table 2. Detonation velocity of LDSC

\begin{tabular}{|c|c|}
\hline Sample $\mathbf{N}^{\mathbf{0}}$ & Detonation velocity \\
\hline \hline 1 & $8077,4 \mathrm{~m} / \mathrm{s}$ \\
\hline 2 & $8015,7 \mathrm{~m} / \mathrm{s}$ \\
\hline 3 & $7925,0 \mathrm{~m} / \mathrm{s}$ \\
\hline The average value & $8006 \mathrm{~m} / \mathrm{s}$ \\
\hline
\end{tabular}

The experimentally determined detonation velocity of LDCS, $8006 \mathrm{~m} / \mathrm{s}$, satisfies the quality requirement (the value is greater than $6000 \mathrm{~m} / \mathrm{s}$ ). Very small differences between the individual measured values and the average value of detonation velocity indicate a homogeneous distribution of density of the explosive's core.

\section{Reliability of the LDSC initiation by the detonation cap DK-8}

Testing the reliability of the LDSC initiation by the detonation cap DK-8 was performed during the technology process development of LDSC as well as during the quality tests (efficiency and precision cutting of various materials by LDSC). During the realization of numerous experiments in the phase of investigation and serial production (quality control), LDSC did not reject the initiation with the detonation cap DK-8. Based on more than 160 experiments, it can be claimed that the reliability of the LDSC initiation by the detonation cap is $100 \%$.

\section{Possibility of the initiation by the initial cap E-67P1}

The possibility of the LDSC initiation by the initial cap E-67 P1 was tested on the original initiator (which is used in the "Canopy cutting system"), designed and made for these experiments.

The initiation of LDSC was realised with a single initial cap E-67 P1 (Fig.9).

The formation of the experimental model (set of initiator and LDSC) is shown in Fig.10-a, and the results of experiments are shown in Fig.10-b. 


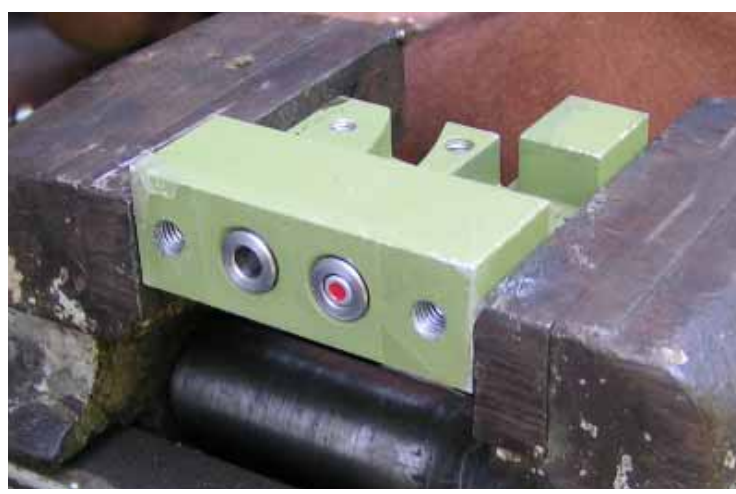

Figure 9. Initiator with one initial cap E-67 P1

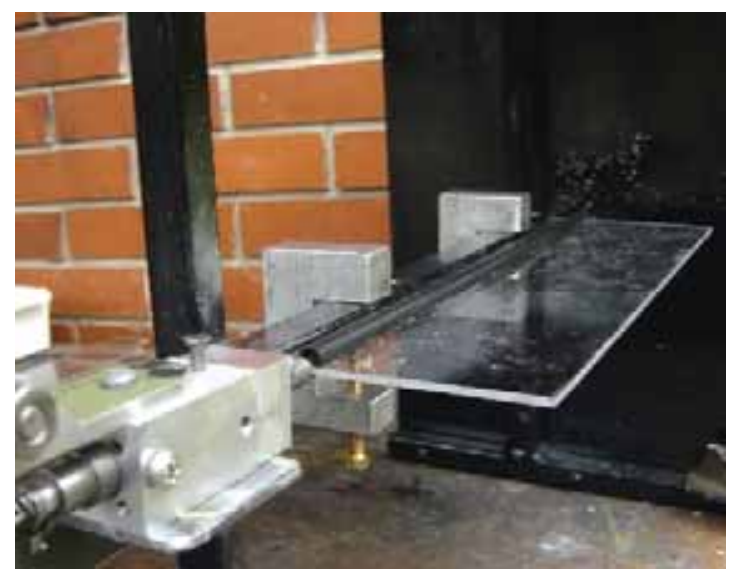

a)

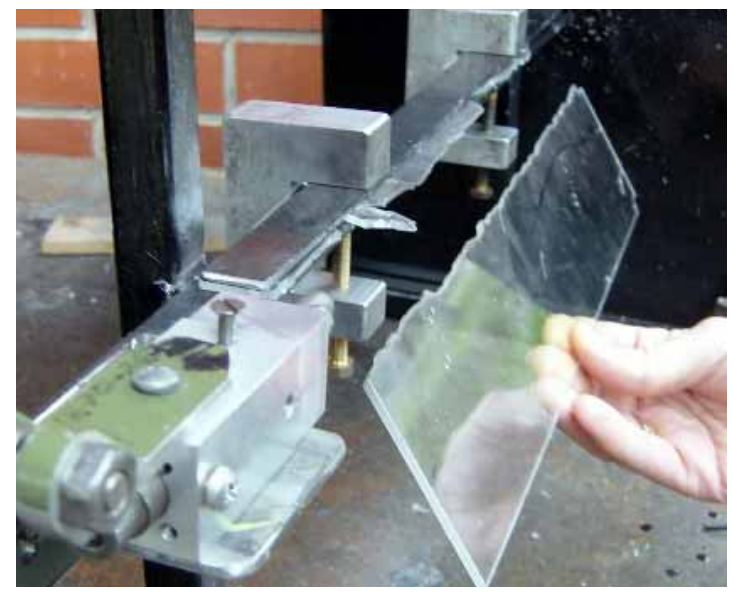

b)

Figure 10. Examination of initiating LDSC by E-67 P1

LDSC were successfully initiated by the initial cap E-67 $\mathrm{P} 1$. The cutting effects on an acrylate glass are the same as the cutting effects initiated with the detonation cap DK-8. Also, in that way, we tested the initiator which is the integral component of the "Canopy cutting system".

Initiation of LDSC in the "Canopy cutting system" is performed by using two caps E-67 P1, initiated at the same time from both ends of the LDSC. In that way, the probability of initiation of LDSC and reliability of cutting of the LASTA's canopy are doubly increased.

\section{Efficiency and precision of cutting the acrylate glass}

Efficiency and precision of cutting the 4-8 $\mathrm{mm}-$ thickness acrylate glass was tested with $40 \mathrm{~cm}$ - length models of LDSC [7]. Models of LDSC were put on an acrylate glass and firmly glued with the adhesive tape. The activation of LDSC was realised with a safety fuse and detonation cap DK-8.
The efficiency and precision of cutting the acrylate glass are shown in Figures 11 and 12.

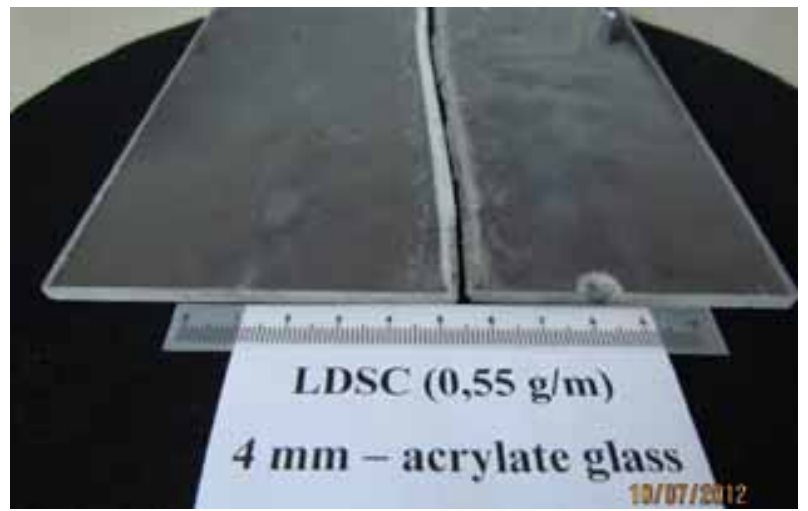

Figure 11. Appearance of the $4 \mathrm{~mm}$ - thick acrylate glass after the detonation of LDSC

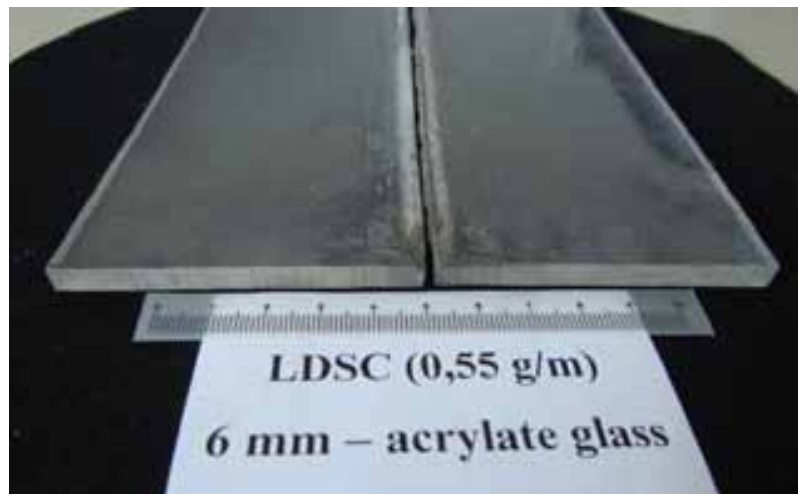

Figure 12. Appearance of the $6 \mathrm{~mm}$ - thick acrylate glass after the detonation of LDSC

Figures 11 and 12 show that the 4 and $6 \mathrm{~mm}$ - thick acrylate glass are cut off along the whole length and the cut is very precise (flat) and sharp.

The $8 \mathrm{~mm}$ - thick acrylate glass is not cut off completely through the thickness of the material.

Efficiency and precision of cutting the aluminum alloy strips

Efficiency and precision of cutting the $0,7-2,5 \mathrm{~mm}-$ thick aluminum alloy strips were tested with $40 \mathrm{~cm}$ - length models of LDSC [7]. Experimental models were prepared in the same way as for the acrylate glass.

Efficiency and precision of cutting the aluminum alloy strips are shown in Figures 13 and 14.

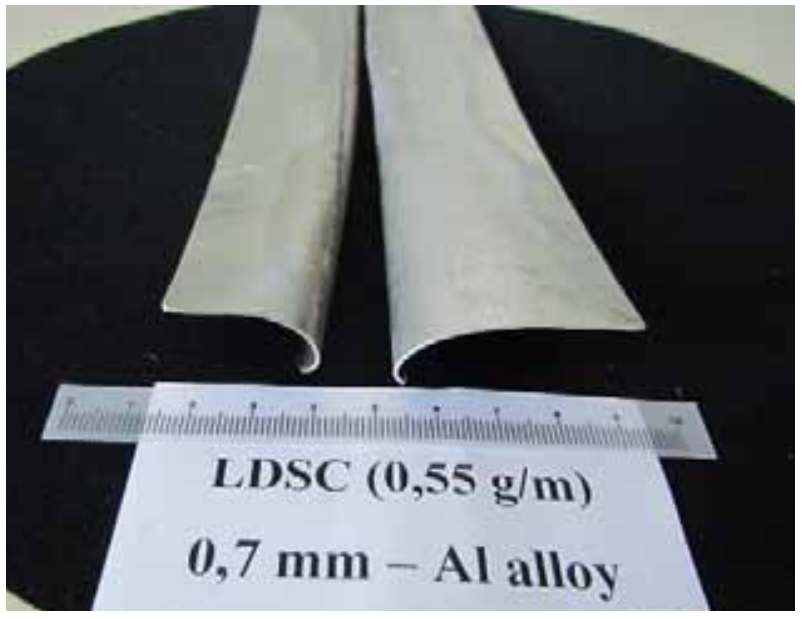

Figure 13. Appearance of the $0,7 \mathrm{~mm}$ - thick aluminum alloy strips after the detonation of LDSC 


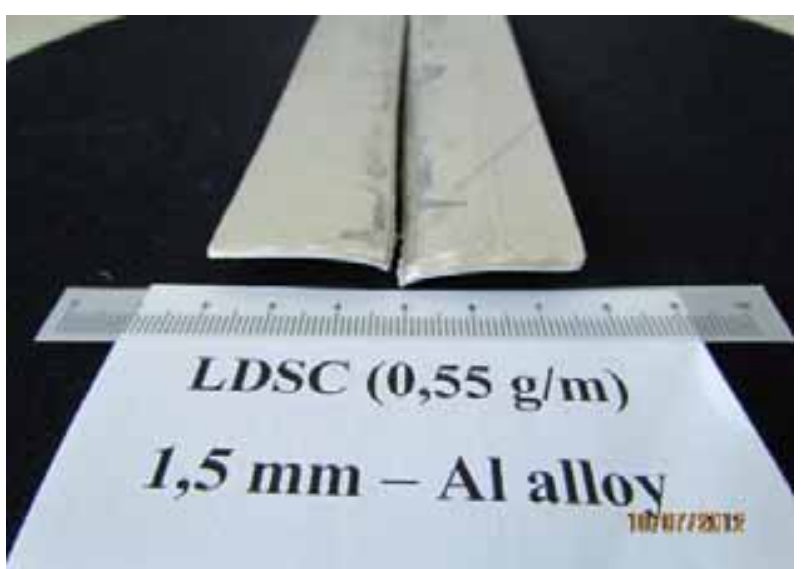

Figure 14. Appearance of the $1,5 \mathrm{~mm}$ - thick aluminum alloy strips after the detonation of LDSC

The Figures 13 and 14 show that the $0,7 \mathrm{~mm}$ and $1,5 \mathrm{~mm}$ - thick aluminum alloy strips are cut off along the whole length, and that the cut is very precise (flat) and sharp.

The $2,5 \mathrm{~mm}$ - thick-aluminum alloy stripes are not completely cut off (through the thickness of the metal strip).

Quality tests of LDSC before they are mounted on the LASTA aircraft

Reliability of initiation and efficiency of detonation of each piece of LDSC were tested according to the defined procedure (100\% quality control) before its mounting on the LASTA canopy.

The test procedure is as follows: LDSC, usually made in a length greater than 6,5 meters, splits in two parts. The first part, a length of $\sim 2 \mathrm{~m}$ was used for testing the reliability of initiation and transmission of detonation along the LDSC. If the above experiment was successful, the second part of LDSC, a length of $\sim 4,5 \mathrm{~m}$, is mounted on the LASTA aircraft. The control tests were performed on white paper strips. LDSCs were activated with a safety fuse and detonation cap DK-8.

The results are documented with photographs made before and after the experiment, as shown in Figures 15 and 16.

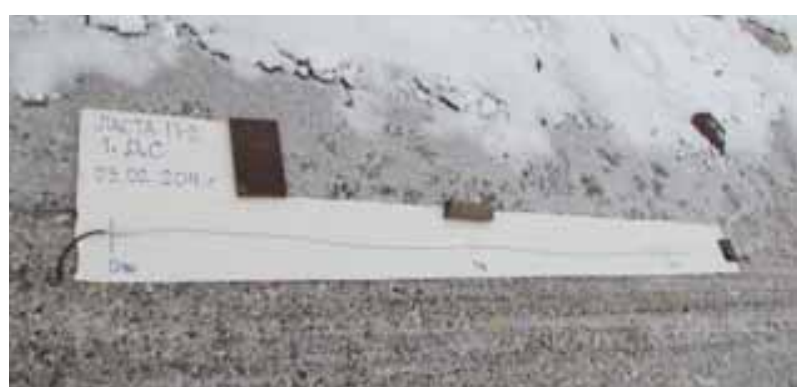

Figure 15. Quality tests: LDSC on paper strips before the detonation

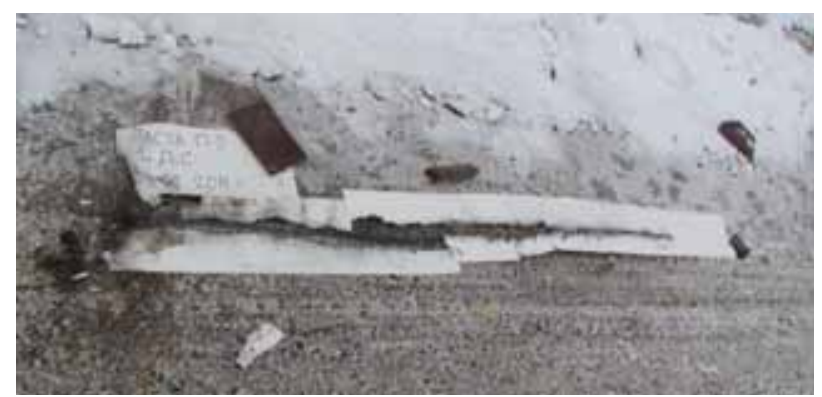

Figure 16. Quality tests: Appearance of paper strips after the detonation of the LDSC
These experiments are an excellent test for rating the homogeneity and continuity of the LDSC explosive core. Namely, only the homogeneously distributed and wellcompacted explosives will be able to accept the initiation and transmit the detonation along the LDSC. The result of this is a high quality cutting of the material - very precise and sharp cut along the whole length of the material. So far, more than 160 such tests were performed with a $100 \%$ success rate.

\section{The cutting of the LASTA canopy}

The "Canopy cutting system" for the LASTA canopy consists of:

- Two LDSC, length of about 4,5 m, each

- Protective moulded rubber and camouflage tape, the same length

- Mechanical assembly for initiation (bullion, the initiator and two initial caps E-67 P1).

Completing and installing the "Canopy cutting system" on the LASTA canopy have the same difficulties because of a high mechanical sensitivity ("vulnerability") of LDSC. According to this, LDSC should not be twisted, bended, crushed, pulled, folded and left during manipulation (transmission, shortening, placing, fixing and gluing on the canopy).

The experiment on the model of the LASTA canopy (control efficiency of the cutting [7]) is presented in Figures 17 and 18.

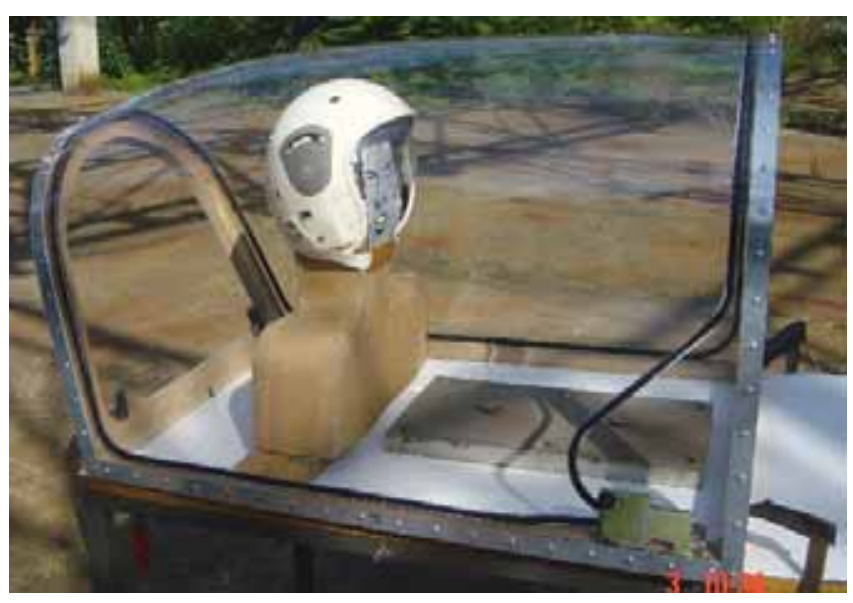

Figure 17. Appearance of the canopy before initiating the "Canopy cutting system" detonation of LDSC

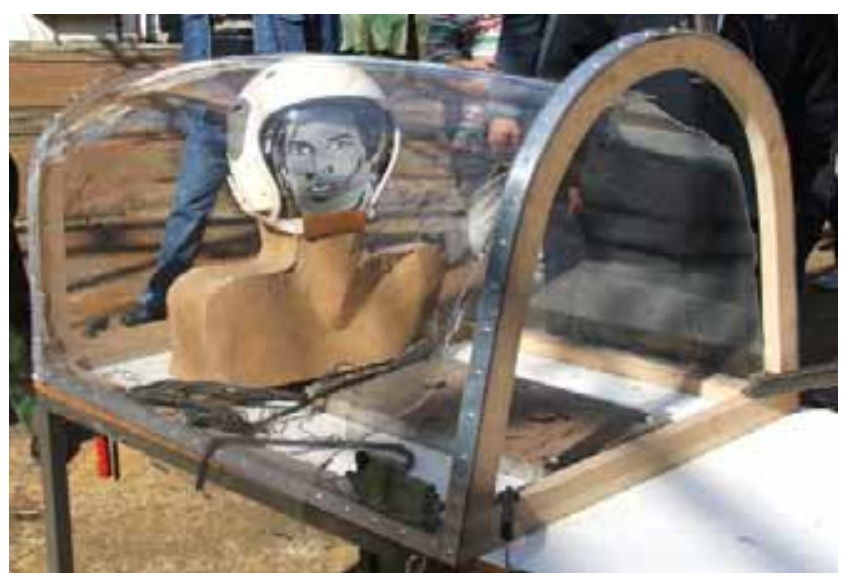

Figure 18. Appearance of the canopy after initiating the "Canopy cutting system" (e.g. detonation of LDSC) 
The results of the experiment showed that the aircraft canopy is completely cut off in the desired manner, regarding the excellent quality of LDSC.

The last experiment was done with the canopy which includes the "Canopy cutting system" placed at the LASTA aircraft in real environment conditions (at the airport runway or hangar) for almost three years. The examination of the "Canopy cutting system" efficiency was filmed by a high-speed camera. Through a large number of frames, we analyzed the activation processes of the initiator, the initiation of LDSC by initiation cap and cutting the acrylic glass of the canopy (Figures 19-24).

Some cutting phases of the co-pilot side of the LASTA canopy are shown in Figures $19-21$.

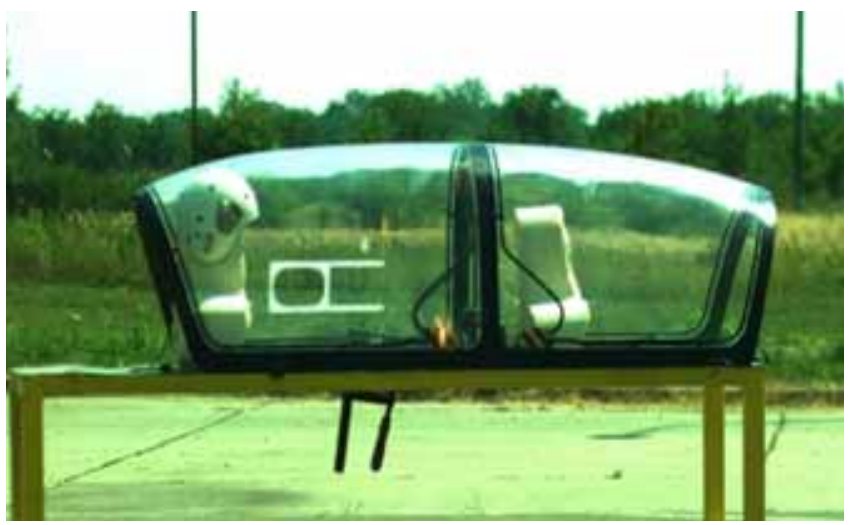

Figure 19. Co-pilot side of the canopy: the activation processes of the initiator (initiating cap)

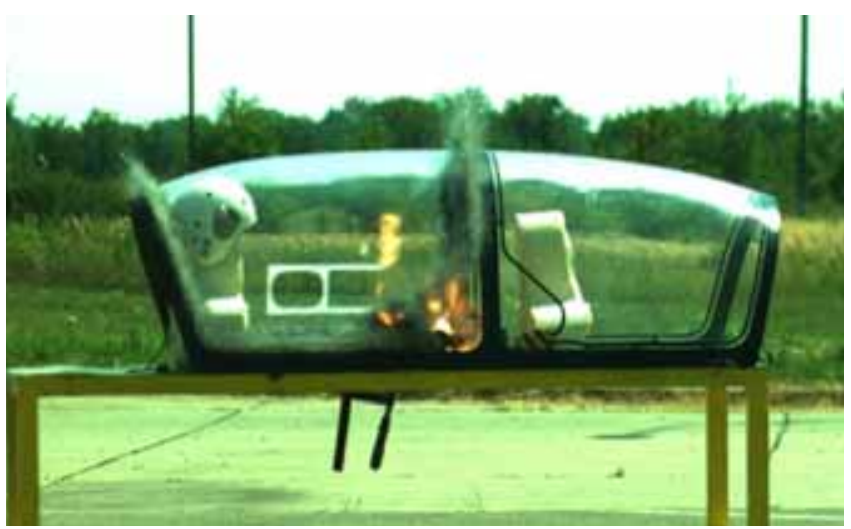

Figure 20. Co-pilot side of the canopy: the initiation of LDSC by initiating cap and cutting the acrylic glass of canopy

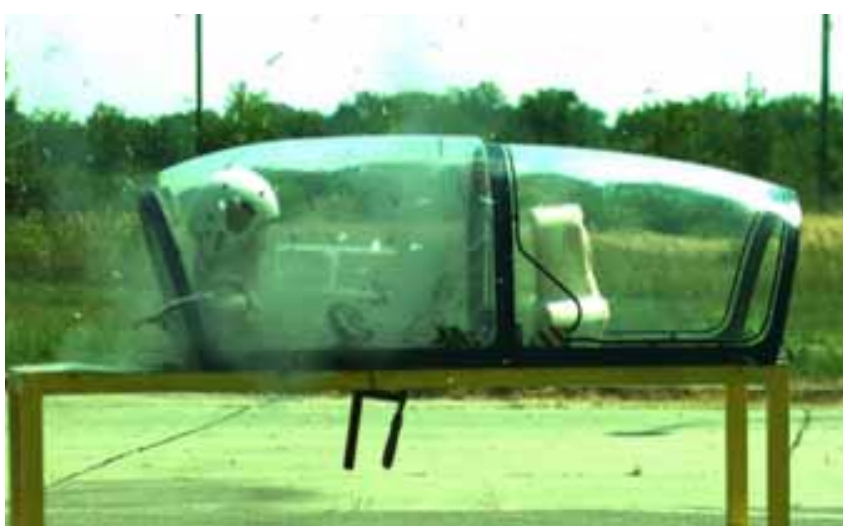

Figure 21. Co-pilot side of the canopy: the end of cutting the acrylic glass

Some cutting phases of the pilot side of the LASTA canopy are shown in Figures 22 - 24.

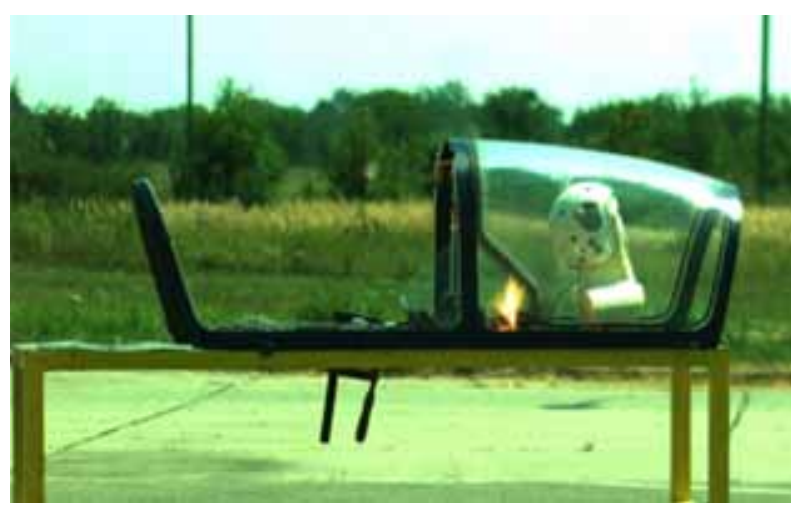

Figure 22. Pilot side of the canopy: the activation processes of the initiator (initiating cap)

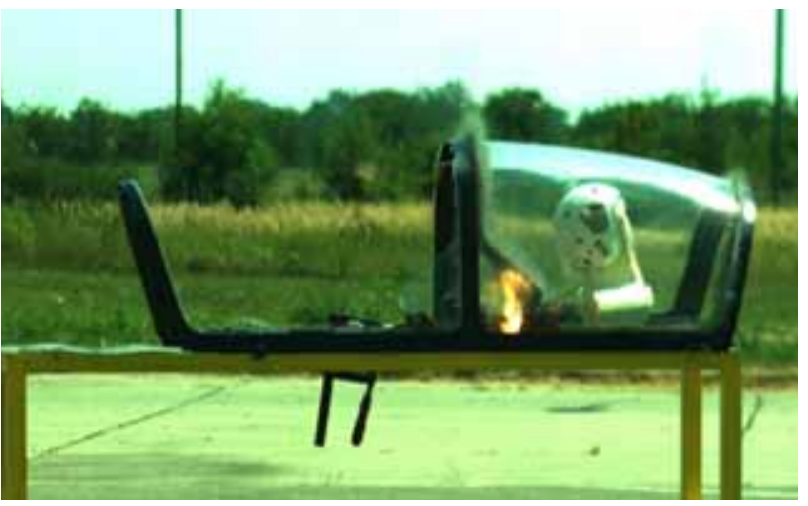

Figure 23. Pilot side of the canopy: the initiation of LDSC by initiating cap and cutting the acrylic glass

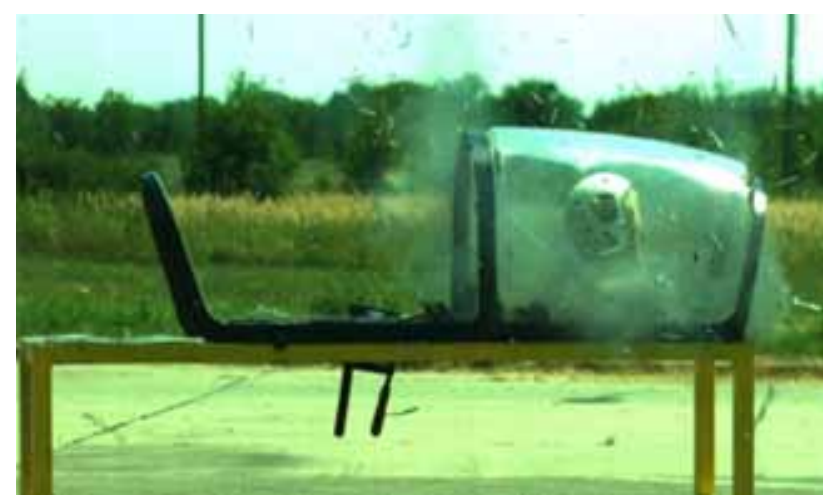

Figure 24. Pilot side of the canopy: the end of cutting the acrylic glass

The results of the experiment show those aircraft canopies are completely cut in the desired manner. This experiment confirmed the excellent quality of the LDSCs that were placed in the LASTA aircraft in real environment conditions (at the airport runway or hangar) for almost three years.

\section{Conclusion}

The production process of a "small-mass" LDSC (linear detonation shaped charge with a small linear mass of the explosive charge, less than $0,6 \mathrm{~g} / \mathrm{m}$ and a large length over $5 \mathrm{~m}$ ) is defined.

The roll-pass design of the rolling technology on the calibrated rollers, which provides all the quality requirements of a "small-mass" LDSC, is designed and applied.

The technology of rolling is used for producing LDSC with a linear mass of the explosive core less than $0,6 \mathrm{~g} / \mathrm{m}$ and the required length. 
Presented experiments show that the tested sample of LDSC accepts the initiation by detonating cap DK-8 and initial cap E-67 P1, and detonates without interruption (throughout the entire length).

Reliability rate of the initiation of LDSC, tested on more than 160 samples, is $100 \%$.

The examined LDSC effectively cut off the $6 \mathrm{~mm}$ - thick acrylate glass, while the thickness of $8 \mathrm{~mm}$ is not cut off. The examined LDSC effectively cut off the $1,5 \mathrm{~mm}$ - thick aluminum alloy strips, while the thickness of $2,5 \mathrm{~mm}$ is not cut off.

The results of the experiments on the LASTA cabin covers confirmed the efficiency of cutting and excellent quality of the built-in detonation blade of the minimum linear mass of the explosive charge.

The test results of cutting on the LASTA aircraft showed that the aircraft canopy is completely cut in the desired manner, regarding the excellent quality of the tested LDSCs.

LDSC that has a small linear mass of the explosive core $(<0,6 \mathrm{~g} / \mathrm{m})$ is used for cutting the various materials by the cumulative jet. The application of LDSC can be very versatile. So far, it is applied to cutting the canopy of the LASTA aircraft in emergency situations, but it can be used for different civilian purposes, too.

It is possible to produce LDSC with a wide range of linear masses of the explosive core, various dimensions of cross-section and great length by changing parameters of the LDSC process technology.

\section{References}

[1] VIGIL,M.G: Design and development of precision linear shaped charges, IX Symp. On. Detonation, 1989, Vol.II, pp. 684-691.

[2] MEYER,R., KOHLER,J., HOMBURG,A.: Explosives, Wiley-VCH, Veinheim, 2007.

[3] MIŠKOVIĆ,B.: Kalibrovanje valjaka $u$ valjaonicama, TMF, Beograd, 1976. ID 030213005.

[4] TERZIĆ,S., VRAČARIĆ,D.: Tehnološki postupak izrade detonacionog sečiva male linearne mase eksplozivnog punjenja, VTI-01-04-0558, Military Technical Institute, Belgrade, SERBIA, 2009.

[5] VRAČARIĆ,D, TERZIĆ,S., ILIĆ,D.: Metalurški aspekti izrade detonacionog sečiva male linearne mase eksplozivnog punjenja, Treći simpozijum o odbrambenim tehnologijama OTEH 2009, 8.-9. oktobar 2009., Military Technical Institute, Belgrade, SERBIA, Zbornik radova, ISBN 978-86-81123-40-9.

[6] VRAČARIĆ,D, ILIĆ,D., TERZIĆ,S.: Tehnologija izrade detonacionog sečiva male linearne mase eksplozivnog punjenja, Tehničko unapređenje, reg. br. rešenja P-243 u Registru Uprave za strategijsko planiranje Ministarstva odbrane Republike Srbije, Beograd, 2011.

[7] VRAČARIĆ,D, TERZIĆ,S., ILIĆ,D.: Efficiency and reliability of cutting by linear detonation shaped charge (LDSC) with small linear mass of explosive core, $5^{\text {th }}$ International Scientific Conference on Defensive Technologies OTEH 2012, Military Technical Institute, 18.-19. September 2012., Belgrade, SERBIA, ISBN 978-86-8123$58-4$.

\title{
Optimizacija procesa izrade, karakterizacija i efikasnost detonacionih sečiva male linearne mase eksplozivnog punjenja
}

\begin{abstract}
U radu je prikazana optimizacija procesa izrade detonacionih sečiva (DS) male linearne mase eksplozivnog punjenja, tehnologijom valjanja. Dati su zahtevi za kvalitet i osnovne karakteristike proizvedenih DS, kao i rezultati ispitivanja pouzdanosti njihove inicijacije i potpunosti detonacije. Prikazani su i analizirani rezultati ispitivanja efikasnosti sečenja detonacionim sečivom dve vrste materijala, različitih debljina. Izvršene su probe sečenja poklopca pilotske kabine aviona LASTA sistemom za sečenje, u statičkim uslovima. Dobijeni rezultati su analizirani i predstavljeni fotografijama.
\end{abstract}

Ključne reči: avion, pilotska kabina, akrilno staklo, detonaciono sečivo, grafitinirani heksogen, tehnološki proces, valjanje, kumulativni efekt, rezultati ispitivanja.

\section{Оптимизация процесса проектирования, характеристики и эффективность детонационных лезвий малой линейной массы взрывчатых зарядов}

\begin{abstract}
Эта статья представляет собой процесс оптимизации создания детонационных лезвий (DS) небольшой линейной массы взрывчатого заряда, технологией прокатки. Учитывая требования к качеству и основным особенностям производства DS, даны и результаты испытаний достоверности их инициирования и полноты детонации. Здесь представлены и анализированы результаты эффективности режущего детонационного лезвия двух видов материалов различных толщин. Тоже проводились испытания резки крышки кабины лётчика самолёта «Lasta» (Ласточка), в статических условиях. Полученные результаты проанализированы и представлены на фотографиях.
\end{abstract}

Ключевые слова: самолёт, кабина лётчика, акриловое стекло, детонационная лезвия, графитированный гексоген, технологический процесс, прокатка, кумулятивный эффект, результаты испытаний. 


\title{
Optimisation du processus de production, caractérisation et efficacité des coupeurs de détonation de petite masse linéaire de charge explosive
}

\begin{abstract}
Ce papier présente l'optimisation du processus de production des coupeurs de détonation (CD) de charge explosive de petite masse linéaire par la technologie de roulage. On a donné les exigences pour la qualité et les caractéristiques de base de CD produits ainsi que les résultats des tests de fiabilité de leur initiation et la plénitude de leur détonation. On a présenté aussi les résultats analysés des recherches sur l'efficacité de la coupe par la détonation pour deux types de matériaux d'épaisseurs différentes. On a effectué les tests de coupe sur la couverture de la cabine de pilote de l'avion LASTA par le système de coupe dans les conditions statiques. Les résultats obtenus ont été analysés et représentés par les photos.
\end{abstract}

Mots clés: avion, poste de pilotage, verre acrylique, coupeur de détonation, hexogène graphite, processus technologique, roulage, effet cumulatif, résultats des recherches. 